TITLE:

\title{
Nitrate reductase activities in plants from different ecological and taxonomic groups grown in Japan
}

\section{$\operatorname{AUTHOR}(\mathrm{S}):$}

Koyama, Lina A.; Terai, Masakazu; Tokuchi, Naoko

\section{CITATION:}

Koyama, Lina A.... [et al]. Nitrate reductase activities in plants from different ecological and taxonomic groups grown in Japan. Ecological Research 2020, 35(5): 708-712

\section{ISSUE DATE:}

2020-09

URL:

http://hdl.handle.net/2433/255259

\section{RIGHT:}

This is the peer reviewed version of the following article: Koyama, LA, Terai, M, Tokuchi, N. Nitrate reductase activities in plants from different ecological and taxonomic groups grown in Japan. Ecological Research. 2020; 35: 708- 712, which has been published in final form at https://doi.org/10.1111/1440-1703.12083. This article may be used for noncommercial purposes in accordance with Wiley Terms and Conditions for Use of Self-Archived Versions. The full-text file will be made open to the public on 19 January 2021 in accordance with publisher's 'Terms and Conditions for SelfArchiving', この論文は出版社版でありません。引用の際には出版社版をご確認ご利用ください。; This is not the published version. Please cite only the published version. 


\section{Title}

Nitrate reductase activities in plants from different ecological and taxonomic groups grown in Japan

\section{Authors}

Lina A. Koyama ${ }^{1,2}$, Masakazu Terai ${ }^{1,3}$, Naoko Tokuchi ${ }^{4}$

\section{Affiliations}

1: Laboratory of Forest Ecology, Graduate School of Agriculture, Kyoto University

2: Laboratory of Biosphere Informatics, Department of Social Informatics, Graduate

School of Informatics, Kyoto University

3: FUJICCO Co., Ltd.

4: Field Science Education and Research Center, Kyoto University

\section{Correspondence}

Lina A. Koyama

Laboratory of Biosphere Informatics, Department of Social Informatics, Graduate

School of Informatics, Kyoto University

Kyoto 606-8501, Japan

Phone: $+81-75-753-3297$

E-mail: linak@bre.soc.i.kyoto-u.ac.jp 


\section{Abstract}

Plants generally use soil inorganic nitrogen, ammonium $\left(\mathrm{NH}_{4}{ }^{-}-\mathrm{N}\right)$, and nitrate $\left(\mathrm{NO}_{3}{ }^{-}-\mathrm{N}\right)$ as sources of nitrogen, an essential nutrient. The assimilation processes after uptake differ considerably from ammonium to nitrate. Nitrate must be reduced to ammonium in plant tissue before it is synthesized to amino acids, while ammonium is directly and immediately synthesized to amino acids after its uptake. Nitrate reductase is an enzyme that catalyzes the first and rate-limiting step of nitrate assimilation, reducing nitrate to nitrite. It is a substrate-inducible enzyme, and the capacity to induce nitrate reductase varies greatly among plant species. In vivo nitrate reductase activity (NRA) is generally measured as a nitrite production rate during incubation using fine cut pieces of plant tissue, and it is applicable as an indicator on plant nitrate use. Here we present in vivo NRA of leaves from a total of 108 species including arboreal trees, small trees, shrubs, herbs, a vine and a moss. For 75 of the species, NRA in fine roots was also determined. At least 20 species in sampled plants were imported and planted for scientific or industrial purposes, but most sampled species were native to Japan. Several inventory studies of plant NRA have been conducted, mainly in Europe, and they provided information on the species-specific capacity of nitrate use by plants in Europe. However, to our best knowledge, there has been hitherto no published inventory of the NRA of plants in Japan where many endemic species are distributed. Our dataset contains plant NRA with species, family name, life form, leaf lifespan (evergreen or deciduous), growth stage, the season of sample collection, growth conditions (natural or cultivated) and other treatments/conditions when applicable. The data provided by this study may contribute to future works that require information regarding the plant species characteristics for nitrate use capacity or nitrate preference. 


\section{Keywords}

Angiosperm; bryophyte; gymnosperm; Japan; nitrate; nitrate assimilation; nitrate reductase activity; plants; soil nitrogen

\section{METADATA}

\section{TITLE}

Nitrate reductase activities in plants from different ecological and taxonomic groups grown in Japan

\section{IDENTIFIER}

ERDP-2019-06

\section{CONTRIBUTOR}

\section{A. Dataset owner}

Name: Lina A. Koyama

Affiliation: Laboratory of Biosphere Informatics, Department of Social Informatics,

Graduate School of Informatics, Kyoto University

Address: Kyoto 606-8501 Japan

Tel: $+81-75-753-3297$

Fax: $+81-75-753-3133$

E-mail: linak@bre.soc.kyoto-u.ac.jp
B. Contact person

Name: Lina A. Koyama 
Affiliation: Laboratory of Biosphere Informatics, Department of Social Informatics, Graduate School of Informatics, Kyoto University

Address: Kyoto 606-8501 Japan

Tel: $+81-75-753-3297$

Fax: $+81-75-753-3133$

E-mail: linak@bre.soc.kyoto-u.ac.jp

\section{GEOGRAPHICAL COVERAGE}

A. Geographical description and Position:

Samples were collected from six locations in Japan, including a growth chamber, a greenhouse, an arboretum, and two plantation sites, in addition to the collection of natural vegetation. Table 1 shows the positions, environmental factors, and descriptions of the sampling sites. 
1 Table 1 Description for sampling sites.

\begin{tabular}{|c|c|c|c|c|c|c|c|}
\hline \multirow[t]{2}{*}{ Site } & \multicolumn{2}{|c|}{ Location } & \multirow{2}{*}{$\begin{array}{l}\text { Elevation } \\
\text { (m a.s.1.) }\end{array}$} & \multirow{2}{*}{$\begin{array}{c}\text { Mean annual } \\
\text { temperature } \\
\left({ }^{\circ} \mathrm{C}\right)\end{array}$} & \multirow{2}{*}{$\begin{array}{l}\text { Mean annual } \\
\text { precipitation } \\
\quad(\mathrm{mm})\end{array}$} & \multirow{2}{*}{ Vegetation type } & \multirow{2}{*}{ Dominant species } \\
\hline & LAT & LON & & & & & \\
\hline Ashiu & $35^{\circ} 18^{\prime} \mathrm{N}$ & $135^{\circ} 43^{\prime} \mathrm{E}$ & $\begin{array}{r}\text { about } 600- \\
700\end{array}$ & 12.2 & 2548 & Cool temperate deciduous forest & $\begin{array}{l}\text { Fagus crenata, } \\
\text { Quercus crispula }\end{array}$ \\
\hline Daisen & $35^{\circ} 21^{\prime} \mathrm{N}$ & $133^{\circ} 32^{\prime} \mathrm{E}$ & about1000 & 10.5 & 2736 & Cool temperate deciduous forest & Fagus crenata \\
\hline Isaki & $35^{\circ} 12^{\prime} \mathrm{N}$ & $136^{\circ} 05^{\prime} \mathrm{E}$ & about 200 & 15.1 & 1475 & $\begin{array}{l}\text { Warm temperate coniferous } \\
\text { plantation }\end{array}$ & $\begin{array}{l}\text { Chamaecyparis } \\
\text { obtusa, } \\
\text { Camellia japonica }\end{array}$ \\
\hline Kamigamo & $35^{\circ} 04^{\prime} \mathrm{N}$ & $135^{\circ} 46^{\prime} \mathrm{E}$ & about 200 & 15 & 1584 & $\begin{array}{l}\text { Warm temperate deciduous } \\
\text { forest/plantation }\end{array}$ & $\begin{array}{l}\text { Quercus serrata, } \\
\text { Quercus glauca }\end{array}$ \\
\hline $\begin{array}{l}\text { Kitashirakaw } \\
\text { a }\end{array}$ & $35^{\circ} 02^{\prime} \mathrm{N}$ & $135^{\circ} 47^{\prime} \mathrm{E}$ & about 100 & 15.1 & 1465 & Arboretum & - \\
\hline Tottori & $35^{\circ} 32^{\prime} \mathrm{N}$ & $134^{\circ} 13^{\prime} \mathrm{E}$ & $0-100$ & - & - & Green house & - \\
\hline Tottori & $35^{\circ} 32^{\prime} \mathrm{N}$ & $134^{\circ} 13^{\prime} \mathrm{E}$ & $0-100$ & - & - & Growth chamber & - \\
\hline Tottori & $35^{\circ} 32^{\prime} \mathrm{N}$ & $134^{\circ} 13^{\prime} \mathrm{E}$ & $0-100$ & 14.9 & 1914 & Coastal sand dunes & $\begin{array}{l}\text { Elaeagnus umbellata, } \\
\text { Vitex rotundifolia, } \\
\text { Artemisia capillaris }\end{array}$ \\
\hline
\end{tabular}




\section{TEMPORAL COVERAGE}

Aug, 1997 - August, 2017

\section{METHODS}

\section{A. Sampling sites}

Samples were collected from the six locations shown in Table 1. The following are additional descriptions for each site.

In Ashiu, the dominant inorganic $\mathrm{N}$ form on the upper slope was $\mathrm{NH}_{4}^{+}-\mathrm{N}$, while it was $\mathrm{NO}_{3}^{-}-\mathrm{N}$ on the lower slope of this site (Tateno and Takeda 2003). In total, 16 species were sampled, and samples of Fagus crenata were collected from both the upper slope and lower slope.

In Daisen, fertilization was conducted from 1987 to 2002, with an annual supply of 5,250 $\mathrm{kg} \mathrm{yr}^{-1}$ ha $(\mathrm{N}: \mathrm{P}: \mathrm{K}=20: 10: 10)$. Samples were collected from the fertilization plot and the control plot in this site.

Isaki was located on a peninsula in Lake Biwa and had been colonized by great cormorants (Phalacrocorax carbo) since 1980-90s (Kameda 2012), and the cormorantderived $\mathrm{N}$ influenced $\mathrm{N}$ dynamics (Hobara et al. 2005). Three sampling locations were selected to represent different levels of cormorant colonization effects at this site; a currently occupied area, a previously occupied but now abandoned area, and a control area never colonized by cormorants. In the currently occupied area and the previously occupied area, both the $\mathrm{N}$ mineralization rate and the nitrification rate were high, and the ratio of nitrification to $\mathrm{N}$ mineralization was close to $100 \%$, suggesting high $\mathrm{NO}_{3}{ }^{-}-\mathrm{N}$ availability in these areas (Hobara et al. 2001).

In Kamigamo, a very low nitrification rate in comparison with the $\mathrm{N}$ mineralization rate was reported for both the organic layer and the mineral soil layer 
(Tokuchi et al. 2002) Accordingly, the dominant inorganic $\mathrm{N}$ form in the soil was $\mathrm{NH}_{4}{ }^{+}-\mathrm{N}$.

Samples from 11 species were collected at this site.

Kitashirakawa is an arboretum of the Field Science Education and Research

Center, Kyoto University, where about 500 species are planted in a 1.3 ha area. Forty-eight species were sampled from this site, including coniferous and broad-leaved species of trees, shrubs, and herbaceous species, including native and imported species.

In Tottori, samplings were conducted under two artificial conditions (greenhouse and growth chamber) and a natural condition (coastal sand dunes).

The greenhouse was located on the campus of the Arid Land Research Center, Tottori University. Imported arid land plant species and domestic plant species were grown in the greenhouse to supply experiments, and 28 species were sampled. They were planted in locally available sand and regularly watered. Three levels of fertilization were applied to four Salix species; non-fertilized $\left(0 \mathrm{~N}-\mathrm{kg} \mathrm{ha}^{-1}\right)$, fertilized $\left(7.4 \mathrm{~N}-\mathrm{kg} \mathrm{ha}^{-1}\right)$ and intensively fertilized (29.4 N-kg ha-1). Yamamoto et al. (2003) described in detail the influence of fertilization on the four Salix species. Eight Fagaceae species grown in the greenhouse were regularly fertilized with 1000-fold diluted Hyponex solution (Hyponex, Japan).

The growth chamber was located on the campus of the Arid Land Research Center, Tottori University. The chamber conditions were set to a temperature of $18 \mathrm{C}$, humidity at $90 \%$, illuminance of 0 lux during the dark period, while in the light period the temperature was set at $25^{\circ} \mathrm{C}$, the humidity at $60 \%$, and illuminance 80,000 lux. During the light treatment, 11 hours of darkness were alternated with 13 hours of light. Coastal sand dunes were located immediately north of the Arid Land Research Center, Tottori University, facing the Sea of Japan. The dunes were surrounded by a Pinus thunbergii plantation mixed with Robinia pseudoacasia established as a windbreak to protect agricultural and residential areas nearby. Since the establishment of the windbreak 
53 plantation, coastal plant species such as Elaeagnus umbellata, Vitex rotundifolia, and

54 Artemisia capillaris began invading the dunes. Soil nitrate pool sizes were spatially and temporally heterogeneous, and minimum and maximum nitrate pool sizes were 0.9 and $240 \mathrm{mg} \mathrm{N} \mathrm{m}{ }^{-2}$, respectively (Lina A. Koyama unpublished data). Samples were collected

57 from 11 species at this site.

B. Sample collection

To avoid the effect of diurnal changes in leaf NRA, samples were collected from 10:00 to 14:00 on sunny days except for growth chamber samples, and were kept on ice until laboratory analysis. Growth chamber samples were collected 5 hours after initiation of the last light period. In the dark treatment, the illuminance was kept to 0 lux after the last dark period for 5 hours, and then the samples were collected.

The in vivo NRA assay was performed based on a modified version of the Jaworski method (Jaworski 1971; Thomas and Hilker 2000; Koyama and Tokuchi 2003). Root samples were washed with tap water, followed by deionized water, to remove soil. About $100 \mathrm{mg}$ (fresh weight) of leaf laminae, needles, or fine roots were cut into small fragments (2.5-mm-diameter disks or about 4- $\mathrm{mm}^{2}$ segments of leaves, and about 2-mm-long needles or roots) and transferred to test tubes. The incubation buffer $(5 \mathrm{~mL})$ was added to the needles and roots, and the tube contents were vacuum infiltrated. The composition of the incubation buffer was as follows: $0.1 \mathrm{~mol} \mathrm{~L}^{-1} \mathrm{KNO}_{3}, 0.1 \mathrm{~mol} \mathrm{~L}^{-1} \mathrm{KH}_{2} \mathrm{PO}_{4}$, and $1.5 \%$ 1-propanol; the $\mathrm{pH}$ was adjusted to ca. 7.5 using a $\mathrm{NaOH}$ solution. The samples were incubated for $1 \mathrm{~h}$ in darkness, and the $\mathrm{NO}_{2}^{-}-\mathrm{N}$ concentration in the incubation buffer was measured as the end-point. Before the measurement, enzyme activity was terminated by 
78 placing the sample vials in hot water $\left(>80^{\circ} \mathrm{C}\right)$. The concentration of $\mathrm{NO}_{2}^{-}-\mathrm{N}$ in the

79 incubation buffer was measured colorimetrically following diazotization (Keeney and

80 Nelson, 1982). The confounding effects of plant pigments were corrected by subtracting

81 the absorbance of controls to which N-naphthylethylene diamine dihydrochloride was not

82 added (Gebauer et al. 1998). A fraction of each leaf sample was oven-dried at $105{ }^{\circ} \mathrm{C}$ and

83 then weighed to calculate the activity per unit dry weight.

84

\section{ACCESSIBILITY}

A. License

This data set is provided under a Creative Commons Attribution-NonCommercial 4.0

B. Location of storage

8. DATA STRUCTURE

A. Data table

Table 2 List of data tables.

\begin{tabular}{|l|l|}
\hline $\begin{array}{l}\text { Data file } \\
\text { name }\end{array}$ & Description \\
\hline Data.csv & $\begin{array}{l}\text { Dataset of plant nitrate reductase activity (NRA) with species taxonomic } \\
\text { and growth conditions descriptions }\end{array}$ \\
\hline
\end{tabular}

96

B. Format type

The data files are presented as ASCII text and comma-delimited (csv) files. 
101 Headers corresponding to variable names (see section 9.D) are included in the first row of

102 the data file.

D. Variable definitions

The variables are listed according to their order of appearance in the data file. The variable names are headers included as the first row in the data file.

Table 3 List of variables in the dataset and their descriptions.

\begin{tabular}{|c|c|c|}
\hline $\begin{array}{l}\text { Data file } \\
\text { name }\end{array}$ & $\begin{array}{l}\text { Variable } \\
\text { name }\end{array}$ & Variable definition \\
\hline \multirow[t]{10}{*}{ Data.csv } & ID & Identification number of each sample \\
\hline & $\begin{array}{l}\text { Scientific } \\
\text { name }\end{array}$ & Identification of taxa (Species) \\
\hline & $\begin{array}{l}\text { Family } \\
\text { name }\end{array}$ & Identification of taxa (Family) \\
\hline & Life form & $\begin{array}{l}\text { Tree*/Small tree*/Shrub*/Herb/Vine } \\
*: \text { Trees are } 10 \mathrm{~m} \sim \text {, Small trees are } 5-10 \mathrm{~m} \text {, Shrubs are } \sim 5 \mathrm{~m} \text { at } \\
\text { maturity. }\end{array}$ \\
\hline & $\begin{array}{l}\text { Leaf } \\
\text { lifespan }\end{array}$ & $\begin{array}{l}\text { Tree, Small tree or Shrub: Evergreen/Deciduous } \\
\text { Herb: Perennial/Annual }\end{array}$ \\
\hline & Leaf NRA & Leaf NRA $\left(\mu \mathrm{mol} g\right.$ dry $\left.w^{-1} h^{-1}\right)$ \\
\hline & Root NRA & Root NRA $\left(\mu \mathrm{mol} g\right.$ dry $\left.w^{-1} h^{-1}\right)$ \\
\hline & Year & The year in which the sample was collected \\
\hline & Month & $\begin{array}{l}\text { The month in which the sample was collected representing the } \\
\text { season }\end{array}$ \\
\hline & Site & $\begin{array}{l}\text { Sample collection site: } \\
\text { Ashiu/Daisen/Isaki/Kamigamo/Kitashirakawa/Tottori }\end{array}$ \\
\hline
\end{tabular}




\begin{tabular}{|c|c|}
\hline $\begin{array}{l}\text { Growth } \\
\text { stage }\end{array}$ & $\begin{array}{l}\text { Growth stage of the individual sample: Mature/Young } \\
\text { tree } / \text { Seedling } \\
\text { *: a young tree is defined as a tree that did not reach the canopy } \\
\text { height. }\end{array}$ \\
\hline $\begin{array}{l}\text { Growth } \\
\text { condition }\end{array}$ & $\begin{array}{l}\text { Growth conditions of the individual samples: } \\
\text { Arboretum/Greenhouse/Growth chamber/Natural/Plantation }\end{array}$ \\
\hline $\begin{array}{l}\text { Treatment / } \\
\text { Condition }\end{array}$ & $\begin{array}{l}\text { Particular treatments or conditions for the individual samples: } \\
\text { Ashiu: Upper slope/Lower slope } \\
\text { Daisen: Non-fertilized/Fertilized } \\
\text { Isaki: Currently colonized by great cormorants } \\
\text { /Previously colonized and abandoned by great cormorants } \\
\text { /Never colonized by great cormorants } \\
\text { Greenhouse: Non-fertilized/Fertilized/Intensively } \\
\text { fertilized } \\
\text { Growth chamber: Light/Dark } \\
\text { See Table } 1 \text { and 6.A Sampling sites for details. }\end{array}$ \\
\hline Remarks & Additional information \\
\hline
\end{tabular}

111 We are grateful for the support of our field and laboratory work provided by Drs. N.

112 Yamanaka, M. Yamamoto, K. Kameda, S. Hobara, K. Fukushima, R. Tateno, and M.

113 Hirobe. The staff of the Arid Land Research Center, Tottori University, and the Field

114 Science, Education and Research Center (former University Forests), Kyoto University

115 also helped us in our field and laboratory work.

10. References

118 Gebauer G, Hahn G, Rodenkirchen H, Zuleger M (1998) Effects of acid irrigation and liming on nitrate reduction and nitrate content of Picea abies (L.) Karst. and Oxalis acetosella L. Plant and Soil 199: 59-70. DOI: 10.1023/A:1004263223917 
Implications of the influence of soil adsorption. Plant and Soil 268: 89-101. DOI: $10.1007 / \mathrm{s} 11104-004-0231-6$

Hobara S, Osono T, Koba K, Tokuchi N, Fujiwara S, Kameda K (2001) Forest Floor Quality and N Transformations in a Temperate Forest Affected by Avian-Derived N Deposition. Water, Air, and Soil Pollution 130: 679-684. DOI: 10.1023/a:1013869115132

Jaworski E (1971) Nitrate reductase assay in intact plant tissues. Biochemical and Biophysical Research Communications 43: 1274-1279.

Kameda K (2012) Population Increase of the Great Cormorant Phalacrocorax carbo and Measures to Reduce its Damage to the Fisheries and Forests of Lake Biwa. In: H Kawanabe, M Nishino, M Maehata (eds) Lake Biwa: Interactions between Nature and People. Springer, Dordrecht, pp. 491-496

Keeney DR, Nelson DW (1982) Nitrogen - Inorganic forms. In: AL Page, RH Miller, DR Keeney (eds) Methods of Soil Analysis Part 2. ASA and SSSA, Madison, WI, pp. 643-698

Koyama L, Tokuchi N (2003) Effects of NO3- availability on NO3- use in seedlings of three woody shrub species. Tree Physiology 23: 281-288.

Tateno R, Takeda H (2003) Forest structure and tree species distribution in relation to topography-mediated heterogeneity of soil nitrogen and light at the forest floor. Ecological Research 18: 559-571.

Thomas F, Hilker C (2000) Nitrate reduction in leaves and roots of young pedunculate oaks (Quercus robur) growing on different nitrate concentrations. Environmental and Experimental Botany 43: 19-32.

Tokuchi N, Fujimaki R, Terai M, Shiroshita Y, Kuroki K (2002) Soil nitrogen dynamics of temperate conifer forest in central Japan: The case study of Japanese cypress forest 
at the Kamigamo Experimental Forest (In Japanese with English abstract). Forest Research, Kyoto 74: 47-52.

150 Yamamoto M, Tamai S, Tokuchi N, Yamanaka N (2003) Effects of fertilization on growth of cuttings in Salix species (in Japanese with English abstract). Journal of the Japanese Society of Revegetation Technology 29: 95-100.

153 